\title{
Assessment Of The Effects Of Time, Synthetic And Botanical Insecticides Spray Regimes On The Abundance Of Predators In Cowpea Production In Kebbi State Of Nigeria.
}

\author{
Abdullahi Maikai Murna ${ }^{1}$ and Ibrahim Salihu Koko ${ }^{2}$ \\ ${ }^{I}$ Crop Protection Department, College of Agriculture Zuru, Kebbi State, Nigeria. \\ ${ }^{2}$ Natural Resources Institute,University of Greenwich, Medway Campus, Chatham Maritme, Central Avenue, \\ Chatham, ME4 4TB, UK.
}

\begin{abstract}
The effect of time, scouting and calendar application of neem kernel extract (nke) as a bio pesticide and commercial chemical insecticide $(30 \mathrm{~g} /$ Cypermethrin $+250 \mathrm{~g} / \mathrm{l}$ Dimethoate) on the abundance of predatory insects was investigated using a farmer participatory research in Zuru local government area of Kebbi state of Nigeria.Volunteer farmers planted their favourite cowpea variety IT89KD-245-1 and the insecticides sprays carried out both on weekly (calendar) and scouting based using action threshold of $60 \%$ flower infestation/damage commenced at 50\% flowering. The result showed that Dipteran predators constituted the majority of the beneficial insects caught, and were mostly Asiliidae and Syrphidae spp. predators' occurrence was mainly at the late flowering stage. Highly significant difference was found in the number of the beneficial insect between treatments. The species distribution difference between the treatments was also highly significant. Predators were less affected by neem sprays than by chemical insecticide, especially when spray frequency was decreased by scouting. Thus, neem spray as a bio pesticide applied on scouting basis is safe to the beneficial insects therefore, compatible with Integrated Pest Management (IPM).
\end{abstract}

Keywords: Botanical insecticide, Cowpea Production, Predators, Spray Regimes, Synthetic Insecticide

\section{Introduction}

The World Health Organization estimated that up to three million cases of pesticide poisoning and 20,000 unintentional deaths occurring annually, mostly in the developing countries [1]. In West Africa, insecticides which are meant for crops such as cotton are now being used on food crops, including cowpea, due to farmers' ignorance of the consequences of poisoning their food crop and themselves [2]. The long term effects of pesticide exposure may include damage to the vital body organs such as liver and kidney most especially when the insecticide usage is not judicious. Apart from their negative effects on human health, chemical insecticides are known to adversely affect the environment by harming the beneficial organism especially the predatory insects. Predators work by consuming their individual insect prey in order to reach maturity and each especially the generalist type normally kills many preys in its lifetime[3]. These beneficial insects are farmers' friends which exert natural control of the damaging insect pests [4]. In Nigeria, Orius sp. (Hemiptera: Anthocoridae) has been found to predate on egg, larvae and adult of M. vitrata[5]. Most local framers might not be aware of this role played the predators in exerting natural control of damaging insects and their ignorance could lead to wiping away of these organisms through careless chemical insecticide usage [6]. In consequence of the absence of natural control exerted by the predators, farmers more and more dependent on the use these chemical insecticides in order to achieve pest control, which eventually puts their heath and the environment at risk [7]. Farmers therefore need the knowledge of other safe alternative means of control. They also need to be taught the knowledge of the role played by predator in exerting natural control of the damaging insects, how to recognise them and the period of their availability so as to take measures to protect them as they carry insecticide sprays. This can only be effectively done through on farm trials like this.

\section{Material and Methods}

The investigation was carried out in Manga Village of Zuru Local Government Area of Kebbi State of Nigeria between July and December 2012. The experiment was an on-farm type involving one factor which was insecticide of two types, commercial insecticide (Cypermethrin + Dimethoate) and 5\% neem kernel extract (nke). The two types of insecticides were applied on calendar (weekly) and scouting (need) basis. The whole experiment was set up in Randomised Complete Block Design (RCB) (see appendix 2.6). Five volunteer farmers were used and the field plots of each farmer represented a block. The treatments were located within these bocks. The resistant cowpea variety IT-245 (Improved Kanannado) was used. Five treatments namely: 1. calendar based commercial insecticide application, 2. scouting based commercial insecticide application, 3 . calendar based nke application, 4. scouting based nke application and 5. unsprayed control, were randomly 
assigned to the sub plots of a replication. Each subplot measured $4 \mathrm{~m} \times 10 \mathrm{~m}$ and contained four rows of cowpea spaced $1 \mathrm{~m}$ apart. The spacing between stands was $0.3 \mathrm{~m}$. The subplots were separated $2 \mathrm{~m}$ apart. Early planting was carried out on $17^{\text {th }}$ July 2008 [8]. Among the numerous advantages of early planting of cowpea is that the crop recovers from early season damage by pests without affecting yield [9]. Four cowpea seeds were planted per hill and later thinned to 2 per stand [10]. Weeding was carried out twice by the same persons (3 and 6 weeks after crop emergence). Measures were taken to avoid biasness in all the farm operations. Farmers were experienced in weeding operations. The same persons did both first and second weeding.

The researcher personally supervised the quality of the weeding by ensuring weeds are properly removed with including their roots especially the perennial ones, or covered with earth in such a manner as to prevent regrowth. Care was taken to ensure that weeding was done during dry and sunny weather conditions to allow weeds to die after weeding. Measures were also taken to avoid bias in harvest. Farmers were experienced people who could distinguish between matured ripened pods and un- ripened ones. Edge effect bias was avoided by demarcating plots and harvesting the entire plot in order to determine plot yield. All experiment plots received same cultural treatment on the same date. The natural enemies were sampled using sweep net from the two inner rows using 20 strokes per sampling unit and the populations of flying natural enemies caught were recorded on the spot. Natural enemies sampling started on the $2^{\text {nd }}$ of November and ended on the $16^{\text {th }}$ of the same month. Also lady beetles (coccinellids) were counted using visual counting technique. Pitfalls were dug within the inner rows used in the sampling areas in order to catch ground dwelling predators. A sample of 25 flowers/flower buds was randomly selected from each of the two sampling units per plot and these were opened and examined on the spot for larval presence/damage. This rapid visual estimate method (RVE) was used to determine flower damage as a result of larvae feeding indicated by dirty frass or exit holes [11]. An action threshold of 60 percent larval infestation/damage [12] was used to indicate the need for pesticide application in the case of scouting based control strategy.

\subsection{Data analysis}

Significant differences in natural enemies' abundance between treatments were compared using the Friedman chi-square. The Wilcoxon signed-rank test was used to compare the total number of natural enemies among the treatments. Cluster analysis was used to determine the relationship between treatments with respect to predator abundance. Diversity index was calculated by dividing the number of species in a treatment area by the total number of the individual in the area. Relative species abundance was calculated by dividing the number of species in a treatment area by the total number of species in all the treatment areas. Percentage larval infestation/damage was determined by dividing the number of flowers/flower buds infested/damaged by the total number of flowers sampled and multiplying the value obtained by one hundred.

\subsection{Predator abundance in relation to time}

\section{Results}

Coccinellidae spp. (Ladybugs) were the only Coleopteran predators caught during the sampling exercise and they constitute $16 \%$ of the total Predators/Parasites caught. They appeared in the first week and continued to increase in the second and third week of sampling. The Dipteran predators/parasites constituted $41 \%$ of beneficial insects trapped (Fig. 1) and were the majority of the predators sampled. Members of this Order such as the Asilidae spp. (Robber flies) (Plate 5) were not present during the first week, but appeared in the second week and increased in number in the third week. They constituted the majority of the Dipterans caught (Table 2). The Tachinidae spp. (Tachinid flies) were absent for most of the time and were only caught during the third week in small numbers (3\%). The Syrphidae spp. (Hover flies) (Plate 1) were present on each sampling date but their populations were observed to be high in the first week, decreased in the second week and rose to its peak in the third week (Table 2). They were the second largest group within their Order (19\%). The Hymenopterans (Wasps) constitute $21 \%$ of the total predators/ parasites sampled and the majority (15\%) were the Polistes spp. (Plate 2) whose number was highest during the first week but began to decline during the second and the third week (Table 2). The Ichneumonidae spp. (Plate 4) only appeared in the third week and their numbers were low (2.4\%). Other Hymenopterans caught were the Vespula spp.(Plate 4), whose appearance was noticed in the first week and reduced in number in the second week then disappeared in the third week. The Anisopterae spp. (Dragon flies) (Plate 6) made their appearance in the second week and increased in number in the third week, as did the Mantidae spp. (Plate $7 \& 8$ ) and the Anisopterae spp.

\subsection{Effect of insecticide treatments on the abundance of predator/parasites}

There were significant differences in the number of the beneficial insects between the treatments (Table 5). Spraying insecticides greatly decreased the number of beneficial insects relative to the unsprayed control plots and this effect was greater for chemical insecticide than for neem and was more pronounced in the calendar-based spray treatments. (Fig.3). Application of chemical insecticide and nke on calendar basis did not 
favour the proliferation of beneficials, as shown by the cluster 1 (Fig. 4). Where fewer neem sprays were applied due to scouting (Only two sprays after action threshold of $60 \%$ flower damage was reached), the numbers of the beneficial insects were similar to the unsprayed plots (Table 4). Generally, fewer Coccinellidae were observed in the commercial chemical insecticides treated plots in comparison with the botanical insecticide. However, the unsprayed controls had the highest number of these predators, followed by the scouting based nke treated plot (Table 4). The highest number of the Asilidae spp. was caught in the scouting based nke treated plots, followed by those of calendar based nke treatment. The lowest number of these predators was found in the calendar based commercial insecticide treated plots. All the Tachinidae spp. sampled were from the unsprayed controls (Table 4). The Syrphidae spp. were present in all the treatment plots but their number was higher in the unsprayed control plots, followed by the scouting based nke treated plots then the calendar based nke treated plots. Both the calendar and scouting based commercial insecticide treated plots sustained few but equal number of these predator. The entire Ichneumonidae spp. were caught in the unsprayed control plots. The highest number of the Vespidae spp. (Polistes spp. and Vespula spp.)were caught in the nke scouting based treated plots, followed by the unsprayed controls. Among these predators only Polistes spp. were caught in the chemical insecticide treated plots. The Anisopterae were caught mostly in the unsprayed controls, followed by the calendar and scouting based nke treated plots. Only one was caught in the calendar based commercial insecticide treated plots (Table 4) As for the Mantidae, most of them were caught in the unsprayed controls followed by nke scouting based treated plots and none was caught in the chemical insecticide treated plots (Table 4) also see fig.2.

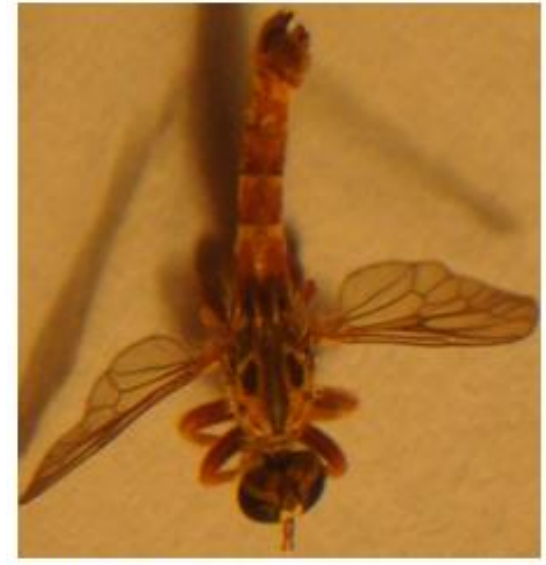

Plate 1 Syrphidae sp.

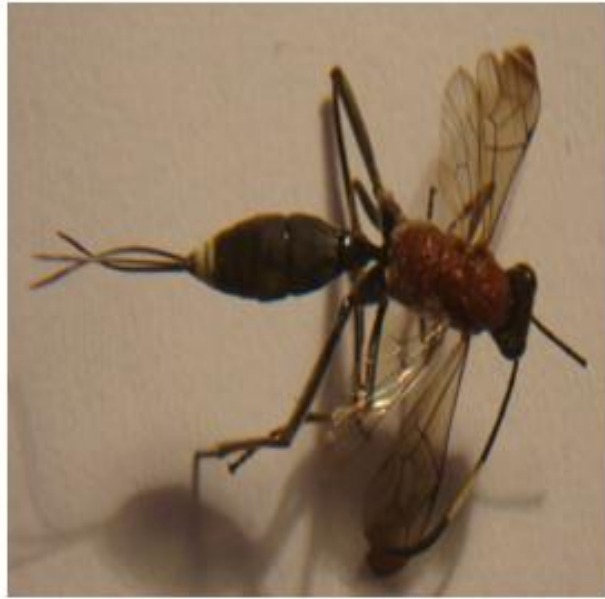

Plate 3 VespidaeIchineumonidae sp.

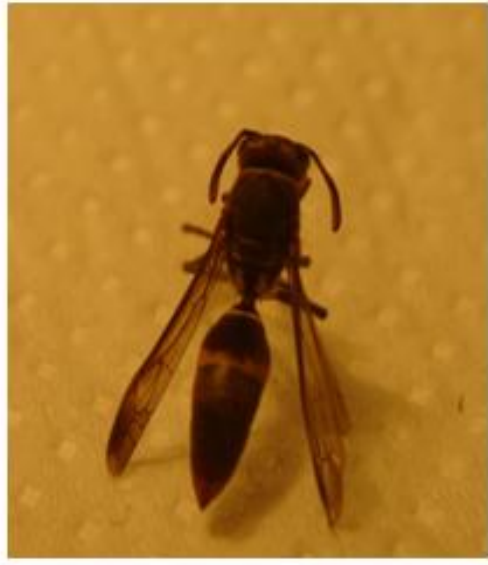

Plate 2 Vespidae: Polistes sp.

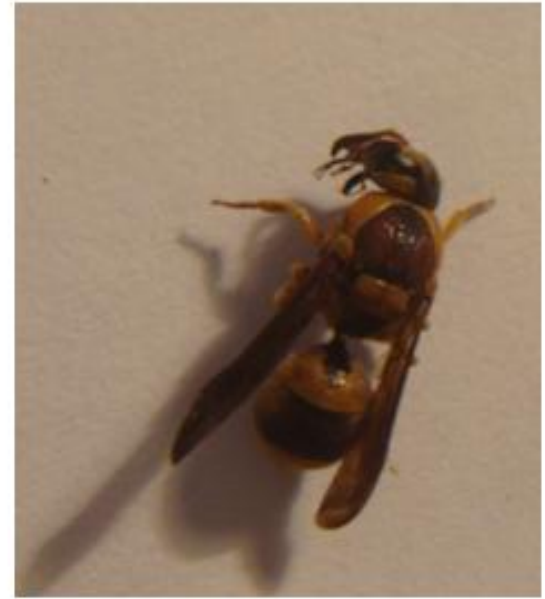

Plate 4 Vespidae: Vespula sp. 


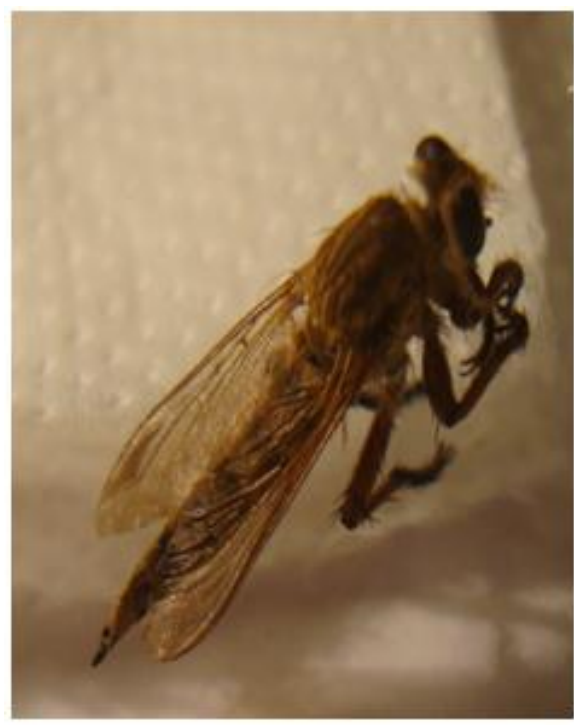

Plate 5 Asilidae sp.

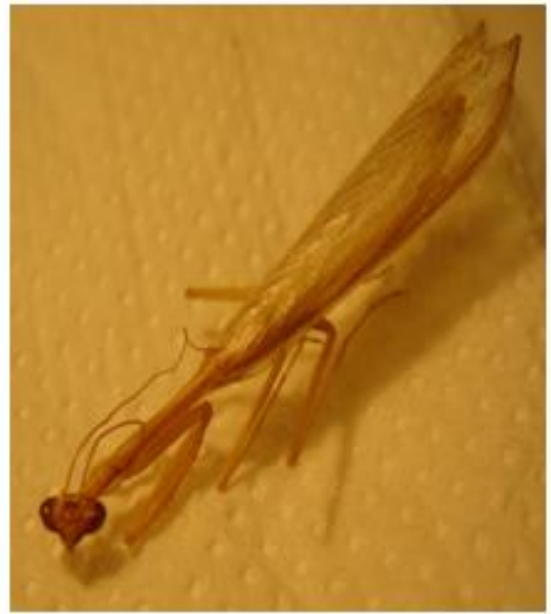

Plate 7 Mantidae: Mantis sp.

(Brown)

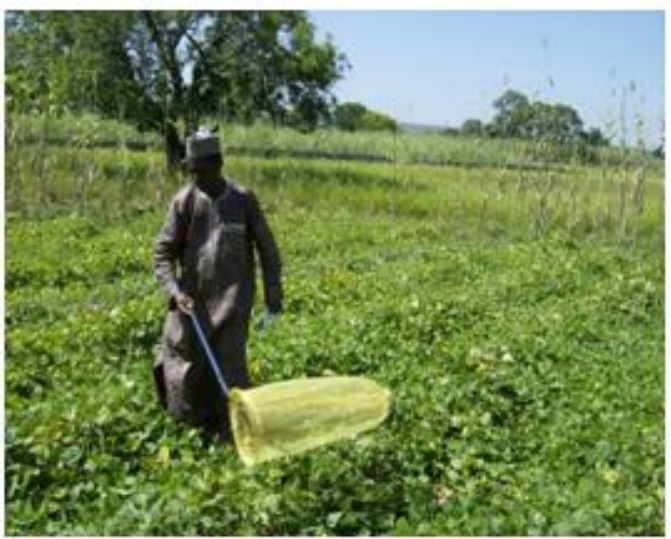

Plate 9 Sampling of predators in experiment plots

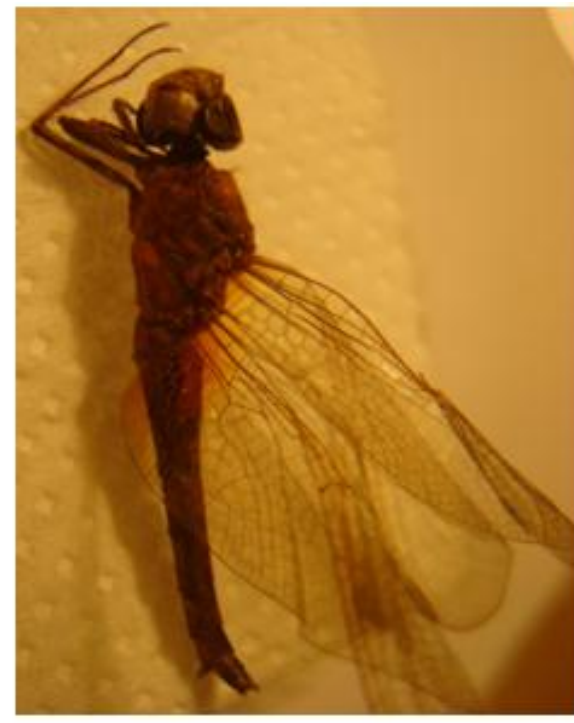

Plate 6 Anisoptera sp.

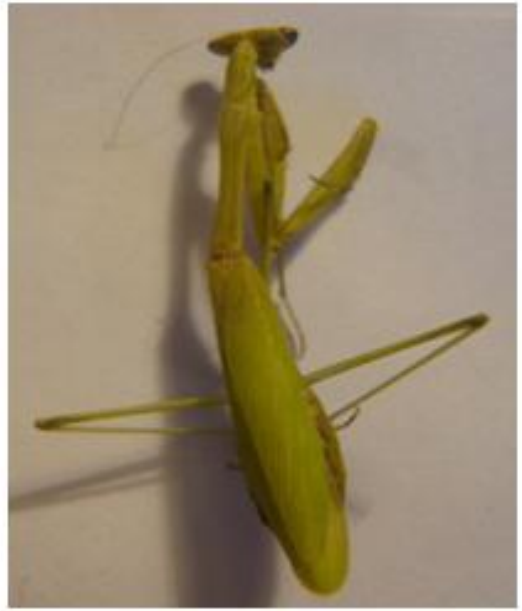

Plate 8 Mantidae: Mantis sp.

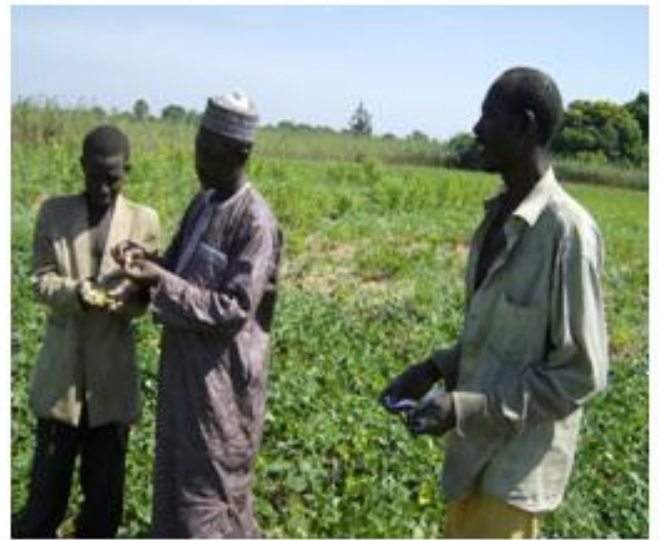

Plate 10 Assessment of larval Infestation/damage with

Farmers 


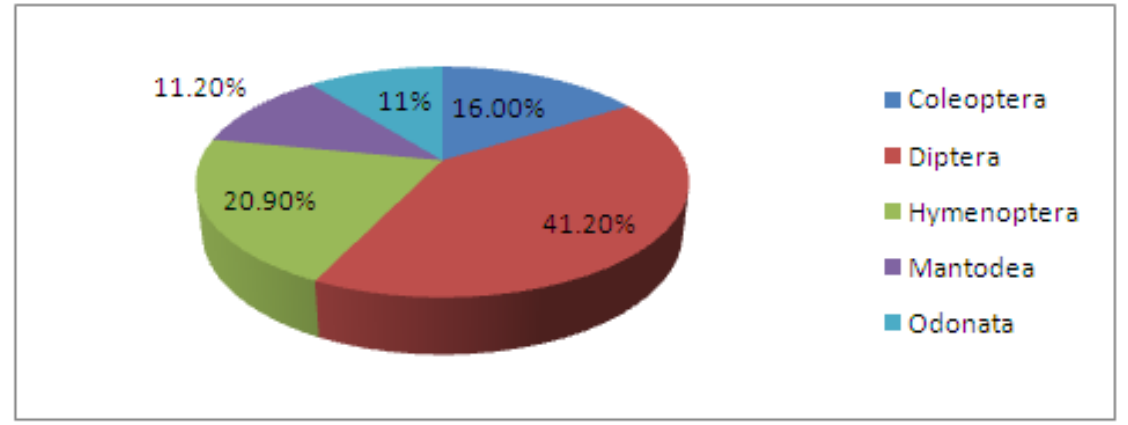

Fig. 1 Relative percentage of the various insects sampled using scoop net in Zuru.

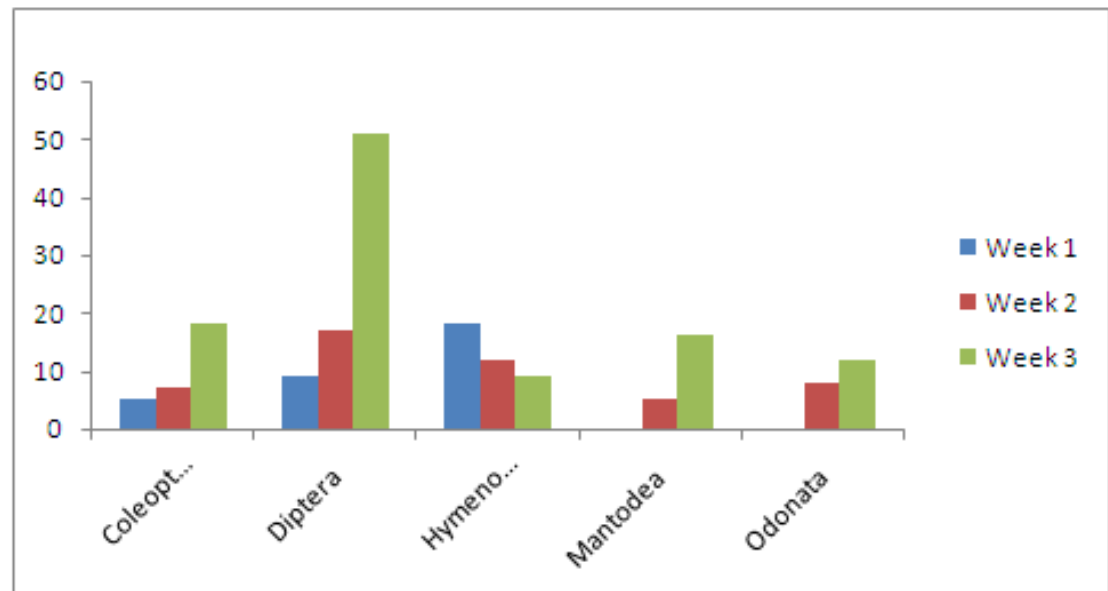

Fig. 2 Effect of time on the abundance of predator/parasites sampled using a scoop net.

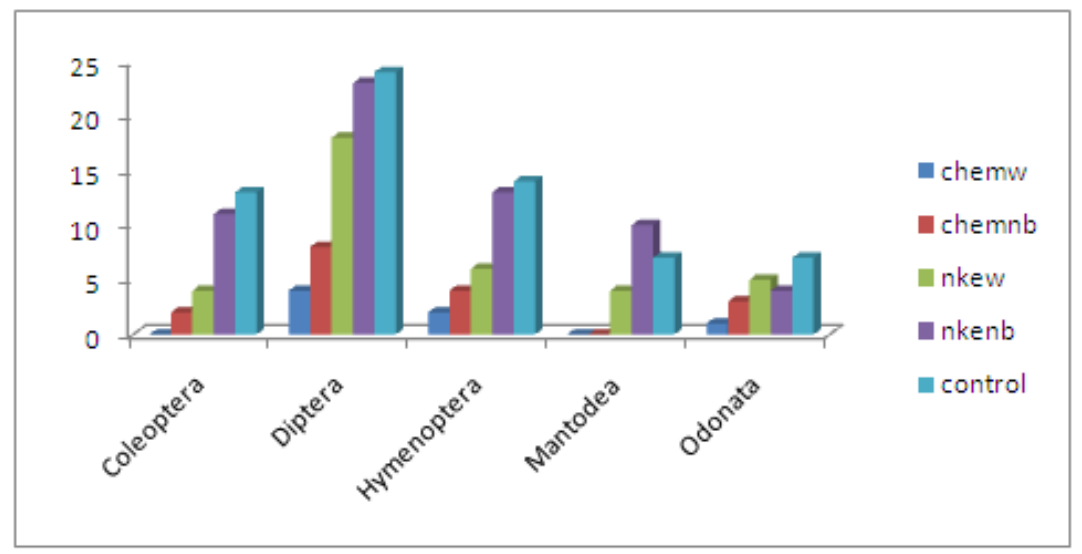

Fig. 3 Effect of insecticide sprays on the abundance predator/parasites sampled using a scoop net.

Table 2 Predators/parasites total numbers in relation to time of sampling

\begin{tabular}{|c|c|c|c|c|c|}
\hline \multirow[t]{2}{*}{ insect } & \multicolumn{3}{|c|}{ weekly catch } & \multirow[t]{2}{*}{ total } & \multirow[t]{2}{*}{$\%$} \\
\hline & 1 & 2 & 3 & & \\
\hline \multicolumn{6}{|l|}{ Coleoptera: } \\
\hline Coccinellidae sp. & 5 & 7 & 18 & 30 & 16.0 \\
\hline \multicolumn{6}{|l|}{ Diptera } \\
\hline Asilidae sp. & Nil & 10 & 30 & 40 & 21.4 \\
\hline Tachinidae sp. & Nil & Nil & 5 & 5 & 2.7 \\
\hline Syrphidae sp. & 9 & 7 & 16 & 32 & 17.1 \\
\hline \multicolumn{6}{|l|}{ Hymenoptera } \\
\hline $\begin{array}{l}\text { Ichneumonidae sp. } \\
\text { Vespidae: }\end{array}$ & Nil & Nil & 4 & 4 & 2.1 \\
\hline Polistes sp. & 10 & 9 & 5 & 24 & 12.8 \\
\hline Vespula sp. & 8 & 3 & Nil & 11 & 6.0 \\
\hline \multicolumn{6}{|l|}{ Mantodea } \\
\hline Mantidae:Mantis sp. & Nil & 5 & 16 & 21 & 11.2 \\
\hline Odonata: Anisoptera sp. & Nil & 8 & 12 & 20 & 10.7 \\
\hline Grand Total & & & & 187 & \\
\hline
\end{tabular}


Assessment Of The Effects Of Time, Synthetic And Botanical Insecticides Spray Regimes On....

Table 3 Wilcoxon signed rank test comparison for total number of predators/parasite between the various treatments

\begin{tabular}{clll}
\cline { 2 - 3 } $\mathbf{s} / \mathbf{n}$ & type of comparison & p-value \\
\hline 1 & control-chemw & $0.0091^{* *}$ \\
2 & control-chemnb & $0.0088^{* *}$ \\
3 & control-nkew & $0.0320^{*}$ \\
4 & control-nkenb & $0.8830 \mathrm{~ns}$ \\
5 & chemnb-chemw & $0.0201^{*}$ \\
Significance codes $0^{\text {'**** }}$ & nkenb-chemnb & $0.0140^{*}$ \\
\hline
\end{tabular}

Table 4 Predator/parasites total numbers trapped in the various treatment plots

\begin{tabular}{|c|c|c|c|c|c|c|}
\hline \multirow[t]{2}{*}{ insect } & \multicolumn{5}{|c|}{ population in the various treatment plots } & \multirow[t]{2}{*}{ total } \\
\hline & chemw & chemnb & nkew & nkenb & control & \\
\hline $\begin{array}{l}\text { Coleoptera } \\
\text { Coccinellidae sp. } \\
\text { Diptera }\end{array}$ & Nil & 2 & 4 & 11 & 13 & 30 \\
\hline Asilidae sp. & 1 & 5 & 11 & 14 & 9 & 40 \\
\hline Tachinidae sp. & Nil & Nil & 1 & 1 & 3 & 5 \\
\hline $\begin{array}{l}\text { Syrphidae sp. } \\
\text { Hymenoptera }\end{array}$ & 3 & 3 & 6 & 8 & 12 & 32 \\
\hline $\begin{array}{l}\text { Ichneumonidae sp. } \\
\text { Vespidae: }\end{array}$ & Nil & Nil & Nil & Nil & 4 & 4 \\
\hline Polistes sp. & 2 & 4 & 6 & 7 & 5 & 24 \\
\hline $\begin{array}{l}\text { Vespula sp. } \\
\text { Mantodea }\end{array}$ & Nil & Nil & Nil & 6 & 5 & 11 \\
\hline $\begin{array}{l}\text { Mantidae: } \\
\text { Mantis sp. } \\
\text { Odonata }\end{array}$ & Nil & Nil & 4 & 10 & 7 & 21 \\
\hline Anisoptera sp. & 1 & 3 & 5 & 4 & 7 & 20 \\
\hline Total & 7 & 17 & 37 & 61 & 65 & \\
\hline Diversity index & 0.57 & 0.29 & 0.19 & 0.13 & 0.14 & \\
\hline Abundance index & 0.12 & 0.15 & 0.21 & 0.24 & 0.27 & \\
\hline
\end{tabular}

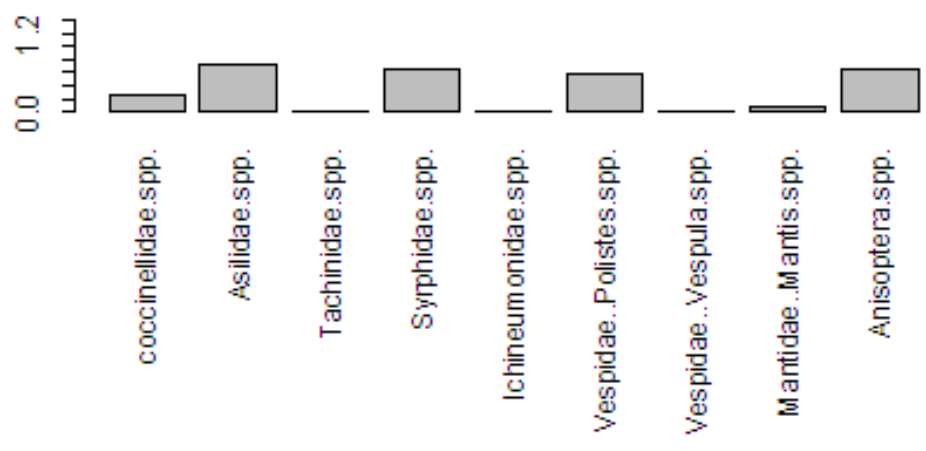

2

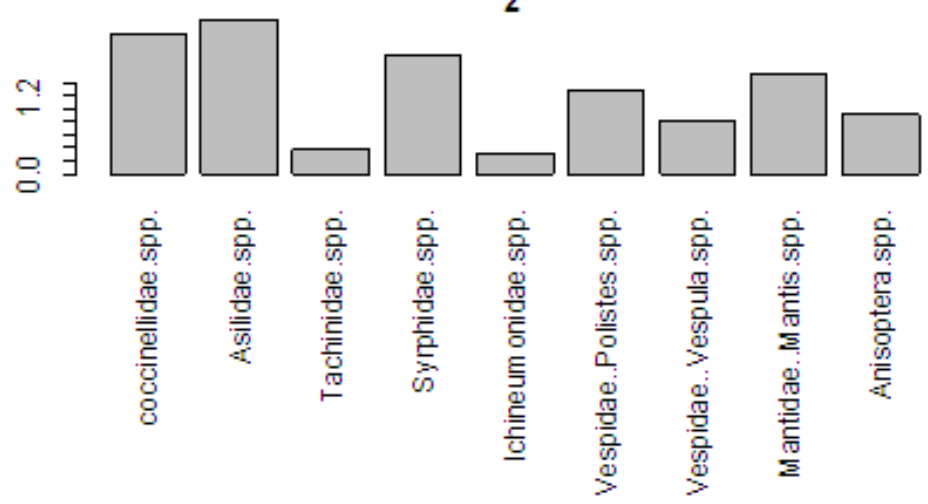

Fig. 4 Relationship between treatments and the predator/parasites abundance (Cluster 1= all chemical treatments and part of the calendar based nke treatments. Cluster $2=$ unsprayed controls, the scouting based nke treatments 
Assessment Of The Effects Of Time, Synthetic And Botanical Insecticides Spray Regimes On....

$\&$ part of the calendar based nke treatments). The scale showed that the average number of insects per specie in the two clusters was 1.2. The difference in the species distribution between the two clusters was highly significant $(\mathrm{P} \leq 0.001)$.

Table 5 Friedman Chi-squared test for significant difference in predators/parasites among treatments

\begin{tabular}{lll}
\hline $\mathbf{x}^{2}$ & df & p-value \\
\hline 26.9565 & 4 & $2.029 \mathrm{e}-05$ \\
\hline
\end{tabular}

\section{Discussions}

The presence of a large number of Coccinellidae spp. in the third week of sampling was due to the abundance of aphids present at that time which coincided with near end of the reproductive stage of the cowpea crop. In Nigeria aphids are known to be migratory in nature and affect mostly the late season cowpea [13]. The Coccillenidae are known to prefer soft bodied insects and both the adult and the larvae have an insatiable appetite for aphids [14]. An adult of these predators can consume more than 100 aphids per day [15]. Their absence in the calendar based commercial insecticide treated plots is an indication of the negative impact this type of spray regime can have on these beneficial insects. Moreover, the type of chemical insecticide used in this study contained an organophosphate compound (dimethoate) whose damaging effect on Coccillenidae has been documented [16]. Chemical insecticides are known to affect them through ingestion of contaminated food, direct contact with the droplets, contaminated plant surfaces and the resultant effect is manifested in various ways such as the immediate disruption in the predatory behaviour, including a reduction in efficiency in locating and capturing of prey [17]. Their presence in both the unsprayed plots and those of the botanical insecticide plots is an indication of the relative harmlessness of this type of insecticide on them. This result is in agreement with the work of [18] whose work found no effect of neem on the predatory activities of Coccinellidae spp. on $N$. viridula eggs and suggested neem as an important component of IPM on this particular insect pest. However, the observed harmlessness of nke on Coccinellidae spp. as shown in this study is in conflict with the findings of [19] who showed that neem in both powder and oil applications, adversely affect the fecundity of coccinellid Harmonia axyridis larvae and adult under laboratory test. [17] also indicated that application of nke at $10 \%$ concentration resulted in $72 \%$ loss of fecundity and $73 \%$ mortality of coccinellid Adonia variegata (Goeze). All the works of these two authors are laboratory tests which may not necessarily be the reality under field conditions where environmental factors such as degradation and plant architecture could affect the pesticide-pest natural enemy interaction, thereby making field performance of insecticide different from laboratory observations [20]. Also the concentrations of nke in the solutions sprayed were higher than used in the present study.

The Asilidae spp. occurrence mainly in the second and the third week, could possibly be due to availability of many different types of flower and pod insects especially bees, wasps, and grass hoppers which are an important food source to these predators [21];[22]. This period corresponds with up to $70 \%$ flowering of the cowpea crop which attracts large numbers of different insects that are ambushed and captured by these predators. Experiments in China showed that the larvae of an asilid Promachus yesonicus Bigot significantly reduced white grubs' populations between $21-99 \%$ in wheat and reduced damage by $68-96 \%$ [23]. Although these predators were present in all the treatment plots, their numbers in the nke treated and control plots were higher in comparison to other chemically insecticide treated plots. The finding of this study is in agreement with those of [24] who reported $20 \%$ increase in asilids abundance in organic fields compared to the conventional farming fields (which use chemical pesticides). Apart from repelling both adult and larvae, disrupting their development processes including sterility, nke is known to affect insect pests in various other ways such as causing confusion (immobilization) in the behaviour of adults [18]. The effect of this is to enhance predation as the prey becomes easier to capture.

The Syrphidae spp. presence at each sampling date may suggest they have a wide range of arthropod food and their preference of the unsprayed control plots and the nke treated plots seemed to indicate that there is little or no detrimental effect of the botanical on them. It has been observed that some Syrphidae species are important flower pollinators and the immature of many species are predators of aphids and other plant bugs and could cause significant reduction in aphids colony where they operate [25];[26]. This may explain why they were mostly in abundance in the third week of sampling, corresponding to the period of availability of flowers and flower insects as well as aphids. Application of broad spectrum chemical insecticides is the main cause of population demise of these important predators. However, it has been observed that neem products especially the oil when spayed directly on these predators is known to have negative effect on them [27]. Neem oil has been documented to have stronger side effect on natural enemies in comparison to oil free preparations and so the use of oil based preparation should be avoided or minimised where natural control is taking place[28]. In another instance it has been reported that neem oil affects only the insects that feed on the crop foliage by ingestion therefore has no any effect on the natural enemies that feed on insects alone [29]. The presence of Mantises in the second and third week may have been due to the presence of many foliage and flower insect 
Assessment Of The Effects Of Time, Synthetic And Botanical Insecticides Spray Regimes On....

such as grasshoppers, butterflies and moths which are important food source for the adults, while the young ones feed on aphids [30]. All these sources of Mantis food were observed to be plentiful on the crop especially at the third week. However, [31] noted that Mantises are easily killed by chemical insecticides especially the broad spectrum types, and this may explain why their presence is only noticeable in both nke treated plots and the unsprayed controls.

The Hymenopteran Polistes spp. appearances in all the weeks of sampling and most especially in the first week, could suggest that they mainly prefer to prey on the remaining foliage beetles whose abundance was observed in the second week. Their scarcity in the third week could be due to the heavy presence of Anisoptera spp. at that time which are known attack and eat many insects including bees and wasps. The Vespula spp. which are known to be the most dangerous among the Hymenopterans whose sting can even be life-threatening in man [32] and whose appearance in the third week of sampling could possibly due to the abundance of flower and flower insects in that particular week. These wasps also known as yellow jackets, have mouth parts that are well developed for capturing insects and sucking of nectar and fruit juices using their long tongue. They are known to feed voraciously on both insect and caterpillars [32]. Organophospahtes are toxic to Hymenopterans and few were found in the plots sprayed with commercial insecticide. Dimethoate is one of the constituents of the type of insecticide used, and in a contact toxicity test of many insecticides such as indoxacarb, endosulfan and dimethoate and three others on two beneficial insects one of which was a wasp (Aphidius colemani Viereck), dimethoate was found to be the most toxic [33]. Hymenopterans were abundant in the neem treated plots, especially where only two sprays were applied. This, may be due to the fact that neem has systemic, repellent and antifeedant insecticidal activity that is devoid of lethal toxins and has little negative effect on wasps and bees [34]. Both the unsprayed controls and the scouting based nke treated plots seemed to provide safe haven to the predators as shown in the cluster 2 of the result section of this study

\section{Conclusions}

Beneficial insects were greatly decreased by spraying with commercial chemical insecticide, but were less affected by neem sprays, especially when spray frequency was decreased by scouting. Most predatory activity occurred after $50 \%$ flowering so any use of broad spectrum at that period could adversely affect the natural control. Thus, neem application on scouting basis can be considered as a safe to the beneficial insects' as such better alternative to chemical insecticide usage for the management of M. vitrata in Kebbi State. Its safety makes it compatible with Integrated Pest Management.

\section{References}

[1]. Meerman, F. Bruinsma, W. Arnold, van Huis, A. Paul, T. \& Weel, P. T. (1997) Integrated pest management: small holders fight back with IPM. LEISA Magazine. [Online] 13(4), 1-5. Available from: http://ebookbrowse.com/integrated-pest-managementsmallholders-fight-back-with-ipm-ileia-publication-pdf-d338944953 [Accessed 2nd May 2013].

[2]. CGIAR SP-IPM (2006) Biological alternatives to harmful chemical pesticides. [Online] CGIAR. IPM Brief Research NO. 4. Available from: http://www.cbd.int/doc/case-studies/tttc/tttc-00147-en.pdf [Accessed 2nd February 2013].

[3]. Coulson, R.N. \& Witter, J.A. (1984) Forest entomology ecology and management. New York, John Willey and Sons.

[4]. Verkerk, R (2001) Farmers' friends: recognition and conservation of natural enemies of vegetable pests. Bell Village, Mauritius, Preci-ex Ltd.

[5]. Tamo, M., Bottenberg, H. Arodokoun, D. \& Adeoti, R. (1997) The feasibility of classsical biological control of two major cowpea insect pests. In: Singh, B. B., Mohan Raj. D. R. Dashiel K. E. \& Jakai L. E. N. (eds) Advances in cowpea research. Ibadan, IITA.

[6]. Bottenberg, H. \& Singh, B. B. (1996) Effects of neam extract applied using the 'broom' method, on cowpea and yield. International Journal of Pest Management, 43 (3), 1.

[7]. Martern, G. \& Williams, D. G. (2006) Getting clean: recovering from pesticide addiction. The Ecologist, 36(10), 50-53.

[8]. Information and Communication Support for Agricultural Growth in Nigeria (2002) Commercial crop production guide series: growing cowpea in Nigeria. [Online] Available from: http://www.cassavabiz.org/agroenterprise/ent\%20images/cowpea 02.pdf [Accessed 20 $0^{\text {th }}$ April 2013].

[9]. Adipala, E., Npala, P. Karugi, J. \& Isubikalu, P. (2000) A review on options for management of cowpea pests experiences from Uganda. Integrated Pest Management Reviews, 5, 187.

[10]. Komolafe, M.F., Adegbola, A. A. Are, L. A. Ashaye T. I. (1985) Agricultural science for West African Schools and colleges $2^{\text {nd }}$ Edition. Ibadan, University press.

[11]. Asante, S. K. Tamo, M. and Jakai L. E. N. (2001) Integrated management of cowpea insect pests using elite cultivars, date of planting and minimum insecticide application, African Crop Science, 9(4), 656-664.

[12]. N RI (1996) A guide to insect pest of Nigerian crops. Chatham, NRI.

[13]. Egho, E.O. (2012) Minimising insecticide application in the control of insect pest of cowpea (Vigna unguiculata (L.) Walp) in Delta State, Nigeria. Sustainable Agriculture Research, 1(1), 1-3.

[14]. University of Florida Institute of Food and Agricultural Sciences (2012) Featured creatures. [Online] Available from: http://entnemdept.ufl.edu/creatures/beneficial/lady_beetles.htm [Accessed 2nd February 2013].

[15]. Roos, D. (2006) Organic pest management. [Online] Available http://economics.ag.utk.edu/hbin/2006/TN\%20Pest\%20Management.pdf [Accessed $3^{\text {rd }}$ March 2013].

[16]. Amin Jalali, M., Van Leeuwen, T. \& De Clercq, P. (2009) Toxicity of selected insecticides to two-spotted Ladybird Adalia bipunctata, Phytoparasitica, 37, 323-324.

[17]. El-Wakil, E., Gaafar, N. Sallam, A. \& Volkmai, C. (2012) Side effects of insecticides on natural enemies and possibility of their integration in plant protection strategies. In: Trdan, S. (ed) Insecticides-development of safer and more effective technologies [ebook] Winchester, INTECH, 4-56. Available from: http://www.intechopen.com/books/insecticides-development-of-safer-and-more- 
effective-technologies/side-effects-of-insecticides-on-natural-enemies-and-possibility-of-their-integration-in-plant-protec [Accessed 29th April 2013].

[18]. Abdullahi, M., Shepard, M. B. \& Mitchell, P. L. (2004). Effects of Neem (Azadiratcha indica A. Juss.) on predators of Nezara viridula (L.) (Hemiptera: Hetoroptera: Pentatomidae). Journal of Agricultural and Urban Entomology, 21(1), 9-13.

[19]. Kraiss, H. and M Cullen, E. (2008) Insect growth regulator effect of Azadiratchin and neem oil on survivorship, development and fecundity of Aphis glycines (Hemiptera: Aphididae) and its predator, Harmonia axyridis (Coleoptera: Coccinellidae), Pest Management Science. [Online] 64(6), 660-668. Available at http://labs.russell.wisc.edu/cullenlab/files/2012/03/Kraiss-andCullen 2008.pdf [Accessed 16th March 2013].

[20]. Cloyd, R. C. (2012) Indirect effects of pesticides on natural enemies. In: Saudarajan, R. P. Pesticides-Advances in Chemical and Botanical Pesticides. [e-book] New York, INTECH, 128-146. Available from: http://www.intechopen.com/books/pesticidesadvances-in-chemical-and-botanical-pesticides [Accessed 23rd March 2013].

[21]. Dennis, S. D., Barnes, J. K. \& Knutson, L. (2008) ZOOTAXA 1868: pupal cases of neartic Robber flies (Diptera: Asilidae). [ebook] Auckland, Magnolia press, 2-5. Available from: http://www.mapress.com/zootaxa/2008/f/z01868p098f.pdf [Accesed 28 th April 2013]. Downham, M. C. A. (2003a) Development of pheromone trapping for monitoring and control of the legume pod borer, Maruca vitrata by small holder farmers in West Africa. Final Technical Report. Natural Resources Institute. Report number: R7441 (ZA0311) Chatham Maritime, NRI

[22]. University of Carlifornia (2008) UC pest management guide lines: how to manage pests. Available from: http://www.ipm.ucdavis.edu/PMG/r107304311.html [Accessded 6th February 2013].

[23]. Symondson, W. O. C., Sunderland, K. D. \& Greenstone, M. H. (2002) Can generalist predators be effective bio control agents? Annual Review of entomology 47, 561-594.

[24]. Pounce, C., Bravo, C. Garcia de Leone, D. Magana, M. \& Alonso, J. C. (2011) Effects of organic farming on plant and arthropod communities: a case study in Mediterranean dry land cereal. Agriculture, Ecosystem and Environment, 141, 193-201.

[25]. Ghahari, H., Hayat, R. Chao, C. \& Ostovan, H. (2008) A contribution to the Dipteran parasitoids and predators in Iranian cotton Fields and surrounding grasslands. Munis Entomology and Zoology Journal, 3(2), 669-703.

[26]. A. 1. Mohammad, R., Verheggen, F. J. Fredric, Francis, F. \& Haubrudge, E. (2010) Intraguild interactions between the predatory Hoverfly Episyrphus balteatus (Diptera: Syrphidae) and the Asian Lady bird (Harmonia axyridis (Coleoptera: Coccinellidae): effect of larval tracks. European Journal of Entomology, 107, 1-3.

[27]. POD (2013) Neem oil spray.[Online] Available from: http://www.podgardening.co.nz/neem-oil-spray.html [Accessed 4th February 2013].

[28]. Infonet-biovision (2011) Plant extract:neem. [Online] Available from: http://www.infonet-biovision.org/default/text/-1/about [Accessed 20th February 2013].

[29]. Sutherland, B. (2010) Neem oil. Urban garden magazine. [Online] 13. Available from: http://urbangardenmagazine.com/2010/11/neem-oil/ [Accessed $18^{\text {th }}$ March 2013].

[30]. Johnson, P. (2012) Praying Mantis food. [Online] Available from: http://www.buzzle.com/articles/praying-mantis-food.html [Accessed 7th March 2013].

[31]. Zinati, G. (2005) Pests and pesticide management practices in nursery operations. Bulletin E299. [Online] 1-6. Available from: http://www.google.co.uk/search?q=g\&rlz=1C1RNPN enGB410GB418\&aq=f\&oq=g\&sugexp=chrome, mod=16\&sourceid=chrome

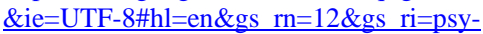
ab\&pq=agriculture $\% 3 \mathrm{~A} \% 20$ facts $\% 20 \% 26 \% 20$ trends $\% 20$ in $\% 20$ south $\% 20$ africa $\& \mathrm{cp}=62 \& \mathrm{gs}$ id=2r\&xhr=t\&q=Pests\%20and\%20pes ticide\%20management\%20practices\%20in\%20nursery\%20operations\&es nrs=true\&pf=p\&rlz=1C1RNPN enGB410GB418\&sclie $\underline{\mathrm{nt}=\mathrm{psy}-}$

ab\&oq=Pests+and+pesticide+management+practices+in+nursery+operations\&gs l=\&pbx=1\&bav=on.2,or.r qf.\&fp=ac82de2c2892 f050\&biw=1366\&bih=624 [Accessed $3^{\text {rd }}$ May 2013].

[32]. University of California (2001) Pest Notes, Publication 7450. Available from: http://apps.cdpr.ca.gov/schoolipm/training/curricula/yellowjackets.pdf [Accessed 6th February 2013].

[33]. Bostanian, N. J. \& AKalach, M. (2004) Contact toxicity indoxacarb and five other insecticides to Orius insidiosus (Hemiptera: Anthocoridae) and Aphidius colemani (Hymenoptera: Braconidae) beneficials used in the greenhouse industry. Pest Mangement Science, 60(12), Abstract.

[34]. Jack, E. R. \& Nancy, A. R. (2000) Insect pest management techniques for enviromental protection. [e-book] Chelsea, Ann Arbor Press, 108. Available from: http://www.slideshare.net/adeladul/insect-pest-management-techniques-for-environmental-protec [Accessed 1st May 2013]. 